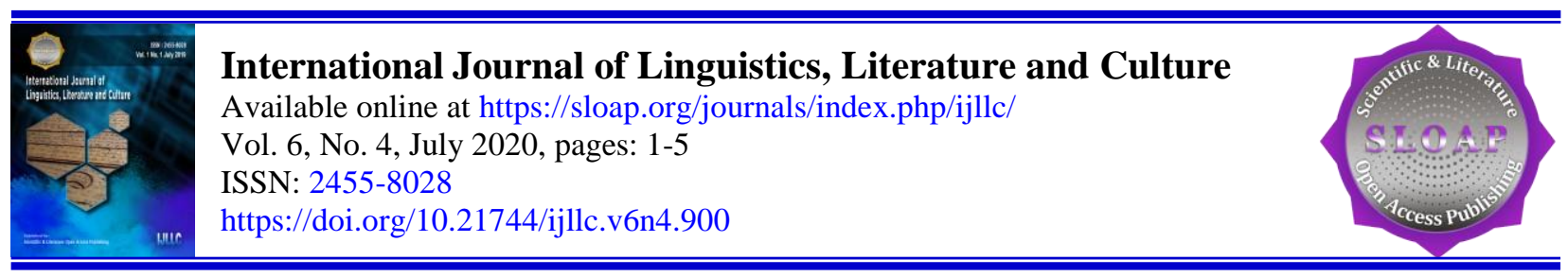

\title{
The Role of the Subject "Literature" in Forming Personality in Modern Secondary Schools
}

Gultas Kurmanbay a

Article history:

Submitted: 18 April 2020

Accepted: 09 May 2020

\section{Keywords:}

critical thinking;

curriculum;

literature;

secondary education;

intercultural relations;

emotional-valuable attitude;

\begin{abstract}
\end{abstract}
In the current time, one of the important tasks of modern schools is to prepare a highly educated student who can think creatively and independently in any situation. In the realization of this task, literature, as a school discipline, which forms the inner world and valuable orientations of students, plays a large role. The study of literature can have crucial importance in the education of the independent personality possessing esthetical taste. Scholars consider the subject of literature as a critical study of literary texts. They clarify that one of the main aims of the subject is the critical analysis of how language is used in different types of texts to identify meaning and find out text elements. With the help of reading various literary texts, students in secondary education of modern schools can receive skills of critical analysis through connecting the meaning of these texts with their lives and the world. Besides, teaching literature in secondary education can provide the ability to imagine the inner and outer worlds of any substance, to solve and investigate important, present, and future problems individually. A considerable number of scholars and studies have attempted to describe the importance of this discipline. One of the descriptions was in terms of the cultural values of specific countries that can be received from literature; another one was about reinforcing the academic curriculum of schools. According to these views, this paper will attempt to examine the level of importance of teaching literature in secondary education as a part of the curriculum.

International journal of linguistics, literature and culture @ 2020. This is an open access article under the CC BY-NC-ND license. Peer-review under responsibility of International Association for Technology, Education and Language Studies (IATELS) (https://creativecommons.org/licenses/by-nc-nd/4.0/).

Corresponding author:

Gultas Kurmanbay,

Nazarbayev University, Nur-Sultan, Kazakhstan.

Email address: gkurmanbay@nu.edu.kz

${ }^{a}$ Nazarbayev University, Nur-Sultan, Kazakhstan 


\section{Introduction}

It is becoming increasingly difficult to ignore the fact that students differ in their skills of reading literary works. However, in many cases some teachers of modern schools ignore this fact, so less capable students have to read the same literary works as their more advanced classmates. This kind of action from teachers can negatively affect students to improve their reading skills. As academic Andrasick (1990) suggests, students should read literature, which suits their ability and literary competence. Teaching literature at secondary schools does not prepare future literary critics, writers or art workers, but this subject related to these spheres and introduces students to some information about these; therefore, literature can help students to be able to think critically, to research scientific works and interpret creations of art. Today, it is obvious that the teaching of literature as a discipline is important in secondary education to enhance the literary knowledge of students.

People, in the broadest sense usually understand the term "literature" as any set of written texts. However, the universal and definite definition for this term is not accepted and not acknowledged. Some studies in language fields give distinctive definitions for this term. For example, Simon \& Delyse Ryan (2004) attempt to define to literature as: "The quest to discover a definition for "literature" is a road that is much traveled, though the point of arrival, if ever reached, is seldom satisfactory. Most attempted definitions are broad and vague, and they inevitably change over time. The only thing that is certain about defining literature is that the definition will change. Concepts of what is literature change over time as well". From this quotation, it can be understood that there were significant changes in the meaning of this term as well as the concept of literature.

Furthermore, the reasons for changes might be by cultural or historical purposes. According to scholars from the field of formalism, literature with poetic effect as "literariness" is a certain type of written work, which is distinguished from ordinary speech. Also, one of the relevant views is that literature belongs to art. Coast (2011), a scientist who did long research in this field, reports that literature is considered as part of the art. He states that literature can create ethical values for people and it is the way of people's expression orally or in writing form. Relying on the above, literature has various definitions in different fields.

\section{Discussion. Cultural importance in teaching literature}

The term "culture" has a wider concept than literature. In this section, the culture will be discussed in terms of relationship with literature as well as the cultural vital role in teaching this subject. Thus, in the teaching of literature, culture has different positions as cultural phenomena in various linguistic, social, historical implementations in every literary work. According to these reasons, every country's civilization is built. It is also important to note that all students in the school have to know not just literary works in their country also literary collections of foreign countries.

Teaching literature to students in secondary schools also by improving reading skills can also help to build wider cultural knowledge of students. One of the popular scholars in terms of cultural knowledge is Hirsch (1988). He, by introducing the term "cultural literacy", found cultural features in literature. Moreover, in his term "cultural literacy", Hirsh (1987) suggests that students not just read literary works, but also, they are introduced to the historical and cultural knowledge of the country. The main point in his suggestion is that people tend to receive national cultural information by reading literary works. By supporting this idea, it can be obvious that literature includes historical and cultural aspects, which might be useful for students in secondary education.

The existence of the term "canon" can prove the importance of culture in the teaching literature. Literary texts which are included the canon can inform school students with the cultural national heritage; therefore students should read these kinds of literary works (Moumou, 2005). The cultural national heritage is often implemented by reading literature and this implementation might be one of the main goals of the teaching literature. The reading of the greatest literary works of world-renowned writers might improve their national cultural knowledge of students.

\subsection{Lesson of literature in modern secondary schools}

Literature at school includes a certain circle of works of fiction, scientific articles about literature, theory, and history of literature bases, the system of oral and written works, which can affect the development of speech and culture of school students. Today, there are a considerable number of modern programs for literature, which can be suitable for 
secondary school students. These programs are considered as basic components of literary education and include standards of secondary education.

Many scholars think that for the stage of adolescents, literature is an independent subject and in this stage, the literary work is studied as a result of the creativity of the writer and esthetical judgment of life. Appleman (2000), suggests that the idea of literature can develop students' perception and understanding of the text as well as the view of the author of a text. He states that the standard of speech, the culture of thinking, and the communication of secondary school students are cultivated. Besides, students' ability to experience empathy is formed, that is why programs of teaching literature for secondary education classes are usually constructed by the concentric principle and on a chronological basis: from folklore and from past literature to the present. Programs of teaching can include sections for independent reading, data according to the literature theory and works of foreign literature, which are studied in parallel with works of native literature. Also, students at this stage can read biographic information of writers and materials, which include a historic-literary basis.

In 2007, Fleming reported that the role of literature at school is the same as literature in life, only at school it is considered as a process of systematic impact on the soul of the students under responsible supervision and the guide of the teacher. He points to the essence of literature as a school subject, which forms the mind of the reader and directs his activity and development. This subject can have a complex structure of teaching: it includes all types of written and oral-literary works from poems to classical novels. Moreover, Fleming (2007), builds construction of teaching literature by steps: relying on reader's preparation, which the child received in primary schools classes, which task is to enter school students into the world of art, to develop their reading susceptibility to prepare for secondary education, where novels of verbal art will be studied on a historic-literary basis. Thus, school students can comprehend a literature role in social movement, in the formation of the human person, in the consciousness of the people and humankind.

The most important purpose of studying literature in modern schools, according to the views of scholars in the field of literature, who are mentioned above, is to familiarize students with art, with the spiritual richness of classics and modern literature, development of art susceptibility. Also, literature can form ideological, political, moral belief of school students and their active living position, esthetical views, tastes, and requirements.

\subsection{The role of literary frameworks in secondary education}

The role of frameworks is considered as one of the important points in the educational curriculum for providing teachers with the methodological tool to motivate students to read literature and to improve their level of literary knowledge. To identify the role of frameworks in secondary education, the project, which is called Literary Framework for Teachers in Secondary Education 2012 (LiFT-2, 2012), played an important role. According to the researches of this project, frameworks can help teachers to find out appropriate literary texts for students at the age between 15 and 17 and identify their reading levels in secondary education. Besides, they suggest that the main aim of literary frameworks is to provide improvement of awareness in the literature of students of all secondary school students without considering their level of literary competence.

It can be believed that literary frameworks can be effective for teachers in terms of planning a way of teaching literature. Teachers should estimate all literary texts to be sure that these texts are appropriate for secondary school students because literary texts are the main factor of students' intellectual demands in learning literature (Beach et al., 2006). For these reasons, frameworks can help teachers to organize the lesson of literature correctly to motivate students to read literary texts more. Furthermore, literary frameworks can make easier for teachers to find out the level of literary competence of students and to use special methods and activities to enhance students' literary reading skills. Analysis and assessment of how much the literary text is difficult can be a crucial aspect of teaching literature.

\section{Conclusion}

Literature as a discipline in the secondary education curriculum is one of the man subjects. There are many reasons to study literature, especially in secondary schools. It is obvious that all students have different literary competence and reading skills and some of them find that literary texts are difficult, some of them think oppositely. Teaching literature at secondary education can form the spiritual and moral abilities of the young generation it provides emotional, intellectual, and esthetical development in the character of school students. Besides, literature can form

Kurmanbay, G. (2020). The role of the subject "literature" in forming personality in modern secondary schools. International Journal of Linguistics, Literature and Culture, 6(4), 1-5. https://doi.org/10.21744/ijllc.v6n4.900 
students' outlook and national consciousness, which affect the spiritual development of the nation. Specific features of literature as a discipline can give students knowledge of the historical and cultural background.

Based on the evidence discussed in this essay, it is obvious that teaching literature in secondary education plays a relevant role in modern times. According to scholars who are mentioned above, teaching literature to secondary school students encourages them to interpret, discuss, and write about literature. This essay also discussed the role of culture and literary frameworks in teaching literature. The cultural importance was explained in terms of the canon contains literary texts which introduce to students national heritage. Literary frameworks were discussed as important tools for teachers to analyses texts, make them relevant for their students, and help them understand the main aspects of those texts.

To conclude, literature provides knowledge of specific intellectual and emotional features of literature and it helps improve the abilities and interests of students who are studying at secondary schools to do independent research and to build professional self-determination. The successful solution of tasks of modern literary education first depends on the teacher who has to be professionally competent, capable to become the organizer, and the coordinator of independent cognitive activity of students. Rational use of traditional and innovative methods at a lesson by teachers on literature lessons might promote the improvement of quality of teaching of national literature and the level of literary competence of students.

\section{Conflict of interest statement}

The author declared that he has no competing interests.

\section{Statement of authorship}

The author has a responsibility for the conception and design of the study. The author has approved the final article.

\section{Acknowledgments}

I am grateful to two anonymous reviewers for their valuable comments on the earlier version of this paper. 


\section{References}

Appleman, D. (2000). Critical in High School English: Teaching Literary Theory to Adolescents. New York, NY: Teachers College Press.

Beach, R., Appleman, D., Fecho, B., \& Simon, R. (2016). Teaching literature to adolescents. Routledge.

Coats, K. (2011). Young adult literature: Growing up, in theory. In Handbook of research on children's and young adult literature (pp. 327-342). Routledge.

Fleming, M. (2007). The Literary Canon: implications for the teaching of language as subject. Strasbourg: Council of Europe.

Hirsch Jr, E. D., Kett, J. F., \& Trefil, J. S. (1988). Cultural literacy: What every American needs to know. Vintage.

Moumou, M. (2005). The literature study programme trial: Challenging constructions of English in the Seychelles.

Ryan, S., and Ryan, D. (2004). What is Literature?. Foundation: Fundamentals of Literature and Drama. http://dlibrary.acu.edu.au/staffhome/siryan/academy/foundation/what_is_literature.html

Kurmanbay, G. (2020). The role of the subject "literature" in forming personality in modern secondary schools. International Journal of Linguistics, Literature and Culture, 6(4), 1-5. https://doi.org/10.21744/ijllc.v6n4.900 